JURNAL PENDIDIKAN AKUNTANSI INDONESIA
Vol. VI No. 1 - Tahun 2008
Hal. 63 - 74

\title{
PERSPEKTIF STRUKTUR ORGANISASI (TINJAUAN SEBAGAI PENGUBAH PERILAKU)
}

\author{
Sri Suryaningsum ${ }^{1}$
}

\begin{abstract}
Abstrak
Struktur organisasi membawa konsekwensi berubahnya perilaku dan nilai karakteristik orang-orang yang berada dalam struktur organisasi tersebut. Struktur organisasi adalah pengontrol perilaku. Perubahan terhadap struktur organisasi sudah pasti dimaksudkan sebagai upaya mengubah perilaku. Perilaku tertentu akan dihasilkan sesuai dengan struktur organisasinya, hal ini bisa saja terjadi untuk berbagai macam orang dengan latar belakang yang berbeda baik sosial dan ekonominya yang dikurung dalam suatu struktur organisasi, pada tataran ini kasuskasus penganiayaan yang terjadi di IPDN misalnya tidak dapat dikatakan sadis untuk struktur yang mengkondisikan seperti itu. Negandhi (1975) menyatakan untuk membuat struktur organisasi yang tepat, dimulai dari melihat karakteristik fenomena birokrasi, dilakukan riset untuk mempelajari organisasi yang kompleks yang dapat menjelaskan sebabsebab adanya struktur khusus dan mencari konsekwensi dari strukturstruktur khusus tersebut pada pola-pola perilaku dan efektivitas dari sebuah organisasi.
\end{abstract}

\section{Kata kunci: struktur organisasi, perilaku, strategi dan struktur organisasi}

\section{Pendahuluan}

Dunia pendidikan masih harus dibenahi karena ternyata kasus kekerasan banyak terjadi di dunia pendidikan. Masih segar dalam ingatan kita bagaimana tragisnya praja IPDN yang menjadi korban pada tahun 2004 yaitu Wahyu Hidayat, dan tahun 2007, yaitu Cliff Muntu yang bahkan disuntik formalin ke tubuhnya. Pada kasus Wahyu Hidayat melibatkan 10 tersangka dan pada kasus Cliff Muntu melibatkan belasan tersangka. Dalam sisi ini Departemen Pendidikan Nasional mendorong Institut Pendidikan Dalam Negeri dan lembaga pendidikan lain di bawah departemen atau lembaga pemerintah nondepartemen menyesuaikan diri dengan ketentuan dalam Undang-Undang Nomor 20 Tahun 2003 tentang Sistem Pendidikan Nasional. Penyesuaian dengan UU harus menjadi pertimbangan dalam menata IPDN menurut

${ }^{1}$ Staf Pengajar Fakultas Ekonomi - UPN Veteran Yogyakarta 
Dirjen Dikti Depdiknas. Sementara menurut Ketua Fraksi Partai Keadilan Sejahtera, menyatakan IPDN harus dibubarkan dan diganti dengan menghidupkan lagi Akademi Pemerintahan Dalam Negeri di tingkat propinsi hal yang diungkapkan Ketua Umum Partai Persatuan Pembangunan dan para politisi lain, bahwa IPDN sebaiknya ditutup, praja dialihkan ke perguruan tinggi yang memiliki fakultas ilmu sosial dan ilmu politik.

Namun pendapat ini juga banyak ditentang sejumlah almunus IPDN yang menyatakan bahwa IPDN tidak boleh dibubarkan, IPDN salah arah karena pemrakarsa dan pengurus IPDN bukan orang yang mengerti. Mereka membangun IPDN hanya berpatokan pada standar perguruan tinggi umum strata satu, tidak mempertimbangkan karakter sebuah sekolah kedinasan. Menurut saya ini merupakan fenomena yang sangat menarik (menyedihkan) dengan adanya pertentangan ini dan hanya akan debat kusir jika tidak melihat hakikat sebuah organisasi dengan tinjauan struktur organisasi.

Struktur organisasi ternyata sangat berpengaruh dalam mengubah perilaku dan nilai karakteristik anggota organisasi. Struktur organisasi adalah pengontrol perilaku. Perubahan terhadap struktur organisasi sudah pasti dimaksudkan sebagai upaya mengubah perilaku. Makalah ini dimaksudkan untuk memahami makna organisasi dengan bahasan khusus struktur organisasi karena struktur organisasi mampu mempengaruhi perilaku dan karakter tertentu orang-orang yang terlibat dan berada dalam bangunan struktur organisasi tersebut. Organisasi artikel disajikan sebagaiberikut: cara struktur mengubah perilaku, struktur yang adaptif, struktur sebagai alat pengatur, struktur kepemimpin dan organisasi.

\section{Cara Struktur Mengubah Perilaku}

Struktur keorganisasian merupakan sebongkah besar keseluruhan lingkungan hidup manusia di dalam organisasi. Dan struktur tersebut benar-benar penting untuk membatasi dan membentuk perilaku. Struktur organisasi adalah pengontrol perilaku. Perubahan terhadap struktur organisasi sudah pasti dimaksudkan sebagai upaya mengubah perilaku. Mengubah struktur, mengubah spesifikasi tentang siapa yang membuat laporan dan kepada siapa seharusnya laporan tersebut diberikan, tentang jumlah tingkatan di dalam hirarki, tentang hak-hak atas pekerjaan, tentangsiapa yang harus memberikan laporan langsung kepada presiden direktur. Semua ini merupakan perubahan struktural. Diberlakukannya sentralisasi ataupun desentralisasi terhadap struktur. Diperlonggar batasan pekerjaan. Membuat batasan kembali terhadap bidang tanggungjawab. Semua ini dilakukan untuk penyusunan kembali terhadap bagan organisasi. Dan dengan melaksanakan hal-hal tersebut maka organisasi akan menghasilkan perubahan perilaku.

Manusia adalah mahkluk yang mencari pemuasan bagi pemenuhan kebutuhan mereka. Secara jelas struktur akan menerangkan kepada kita tentang jensi perilaku yang bagaimana yang akan mendatangkan hukuman. Manusia merupakan penyeimbang yang hebat. Situasi-organisasi yang baru menuntut para anggotanya untuk menyeimbangkan diri mereka. Perilaku akan berpengaruh kepada sikap, demikian pula sebaliknya. Situasi organisasi menuntut perilaku tertentu misalnya bahwa seorang karyawan harus datang di kantor pada jam 07.30 WIB maka sikapsikap yang pantas juga menyusul. Kelompok akan menekan individu untuk menyesuaikan diri dengan standar setempat. Organisasi penuh dengan kelompokkelompok yang terancang secara struktural yang mau tidak mau memaksakan 
keseragaman. Dan banyak alasan yang lainnya bahwa organisasi merupakan suatu alat yang hebat untuk mengubah perilaku.

Perilaku tertentu akan dihasilkan sesuai dengan struktur organisasinya, hal ini bisa saja terjadi untuk berbagai macam orang dengan latar belakang yang berbeda baik sosial dan ekonominya yang dikurung dalam suatu struktur organisasi. Akibatnya akan menghasilkan perilaku tertentu untuk misalnya kalangan militer, universitas, dan bisnis. Dan hal ini sebenarnya tidak perlu heran dengan kondisi yang terjadi beberapa waktu lalu di IPTDN, tidak dapat disebut tindakan yang sadis bagi yang ada dalam struktur organisasi yang dikondisikan demikian, misalnya lagi penganiayaan yang sering dlakukan oleh para sipir penjara terhadap narapidana, ciriciri kepribadian para perawat di rumah sakit juga tidak dapat disebut sebagai perlakuan yang kejam terhadap pasien, demikian juga kita tidak dapat menyebutkan bahwa perilaku pembunuh yang dimiliki oleh para prajurit Nazi merupakan kelemahan dari kepribadian mereka ataupun merupakan kelemahan khusus dari "mentalitas Jerman".

\section{STRUKTUR YANG AdAPTIF}

Dewasa ini perubahan lingkungan bisnis yang berjalan dengan kecepatan tinggi menyebabkan perusahaan mempunyai waktu yang sempit untuk membangun struktur organisasi yang dapat meningkatkan fleksibilitas, daya kreasi, dan daya tanggapanya terhadap perubahan. Semakin lama suatu perusahaan membangun struktur organisasi, semakin jauh pula kita tertinggal dari pesaing. Terlebih, sebagai akibat otomatisasi dan penerapan teknologi informasi secara progresif, perubahanperubahan terjadi secara radikal dalam berbagai proses pekerjaan. Menghadapi gejolak perubahan tersebut, struktur organisasi tradisional yang birokratik dan mekanistik akan mengalami kesulitan besar. Struktur birokratik akan terjerumus pada jurang yang sangat dalam akibat ketidakmampuan mengadaptasikan dirinya terhadap percepatan perubahan lingkungan bisnis. Ketika para pesaing telah mengadopsi kemajuan teknologi untuk membongkar habis jaring-jaring birokrasi, maka para pengguna organisasi birokratik tinggal menunggu kepunahannya.

Prinsip-prinsip apa saja dalam pengorganisasian yang perlu diubah agar organisasi dapat ditransformasikan menjadi struktur yang lebih adaptif? Menurut Dr. Hani Handoko yang diwawancarai Usahawan (1996), ada sejumlah prinsip pengorganisasian klasik yang perlu diganti dengan berbagai prinsip konseptual baru yang lebih sesuai dengan era pengetahuan. Pertama, konsep hirarki ke pasar jaringan. Selama tahun 1980-an, kita menyaksikan pemisahan antara apa yang terjadi dalam organisasi dengan apa yang terjadi di luar organisasi. Mekanisme pengendalian yang dominan di dalam organisasi adalah hirarki atau rantai komando, sebagai sarana pengorganisasian orang dalam berbagai peran mereka. Mekanisme ini beroperasi dengan perbedaan "status" secara vertikal, terutama ditujukan pada pengaturan hubungan sosial. Sedangkan mekanisme pengendalian yang dominan di luar organisasi adalahpasar, mekanisme pasar diarahkan terutama pada regulasi hubungan bisnis. Mekanisme ini mulai mengurangi perbedaan status vertikal, mengganggu harmoni, menstimulasi kepentingan diri, dan mengancam secara konstan kemungkinan terjadinya diskontinuitas. Sekarang, kecenderungannya berubah, orang-orang di dalam dan di luar organisasi menjadi semakin dekat. Di luar organisasi, yaitu pasar, kita menyaksikan meningkatnya hubungan antar organisasi dalam bentuk merger, aliansi, joint ventures, franchises, dan bentuk-bentuk 
partnership lainnya. Sedangkan di dalam organisasi, terjadi perkembangan memanagemen unit yang otonom dan terdesentralisasi, sehingga mekanisma pasar menjadi alat pengendalian. Guna berlangsungnya komunikasi langsung antar unit, dituntut penerapan jaringan. Jaringan ini dimungkinkan oleh kemampuan teknologi informasi modern. Berbagai jaringan bisa dipandang sebagai kelompok-kelompok karyawan (baik di dalam maupun di luar organisasi) yang menggunakan teknologi informasi untuk memfasilitasi komunikasi yang cepat dan sering. Konsep jaringan ini lebih dinamis dan lebih organik ketimbang hirarki fungsional. Jaringan tidak berarti semua hirarki dihapus, melainkan hanya menyusun kembali peran dan fungsinya, melalui strategi koordinasi yang berbeda. Kedua, proses integratif dan kolaboratif. Stratifikasi hirarkis organisasi, dimana thinking dan doing terpisahkan, perlu dihilangkan. Melalui pengorganisasian proses kolaboratif berbagai gagasan, orang, proses, dan sumber daya dalam organisasi, maka thinking dan doing tidak lagi dipisahkan, melainkan diintegrasikan. Seluruh jajaran organisasi dituntut untuk selalu menggapai pemikiran orang atau bagian lain agar bisa bertindak dengan satu pola. Secara esensial, struktur dengan orientasi proses integratif mempunyai rancangan dengan tim sebagai building blocks (team based organization), dan bersifat lebih organik, bukan mekanistik. Struktur perusahaan akan menjadi lebih sederhana dan flat. Struktur berdasarkan tim meningkatkan kecepatan dan kejelasan komunikasi, serta memungkinkan konsentrasi energi organisasional dan sumber daya perusahaan. Peter Drucker mengibaratkan bahwa model organisasi tim yang lebih ramping dan flat sebagai suatu orkes simponi. Dalam orkes, para pemain dengan berbagai keahlian yang berbeda, berkonsentrasi untuk bermain sesuai dengan kompetensi profesional di bawah pimpinan seorang konduktor yang mengkoordinasikan kinerja keseluruhan. Model organisasi "baru" ini menekankan hubungan antar-pribadi, komunikasi dan fleksibilitas untuk mengkombinasikan sumber daya.

Ketiga, metafora organisasi hypertext, oganisasi ini terdiri atas tiga jenjang, yaitu sistem bisnis, tim projek, dan basis pengetahuan. Persyaratan kunci adalah kapabilitas strategik untuk mendukung akuisisi, kreasi, eksploitasi, dan akumulasi pengetahuan baru dengan basis kontinyu dan berulang dalam proses siklikal. Proses penciptaan pengetahuan dikonseptualisasikan sebagai suatu siklus pengetahuan dinamis secara mudah melintasi tiga jenjang. Tujuannya adalah memandang birokrasi dan tim sebagai komplementer. Keempat, organisasi lateral. Kecepatan dalam era telah menjadi kriteria sukses yang paling menentukan. Waktu telah menjadi komoditi yang mahal dan langka. Organisasi lateral memberikan fleksibilitas yang diperlukan untuk menyesuaikan diri dengan perubahan dan mempunyai kapabilitas untuk menghasilkan kecepatan. Kolaborasi horizontal sering lebih baik dan cepat dibanding menggunakan hirarki. Fokusnya adalah menyenangkan pelanggan. Tetapi organisasi lateral bukanlah obat mujarab, yang terpenting adalah matching antara tipe dan jumlah organisasi lateral dengan persyaratan koordinasi lateral untuk mengeksekusi strategi.

\section{Strategi Mempengaruhi StrukTUR}

Struktur kelembagaan telah menawan anggota organisasi sampai pada taraf tertentu. Struktur keorganisasian merupakan sebongkah besar keseluruhan lingkungan hidup manusia di dalam organisasi. Dan struktur tersebut benar-benar penting untuk membatasi dan membentuk perilaku. 
Struktur merupakan suatu alat yang penting untuk mengatur karena berbagai macam alasan, yaitu:

1. manager juga harus tinggal di dalam bangunan struktur yang dia susun, struktur yang dibuatnya bisa memberi kebebasan atau membatasi gerak dirinya maupun para anak buahnya

2. struktur merupakan pegangan yang bisa diputar-putar oleh sang manager untuk mengubah pelaksanaan kerja organisasinya

3. struktur mempengaruhi perilaku orang-orang yang bekerja di dalamnya, dengan mengubah struktur maka bisa mengubah perilaku

Struktur kelembagaan telah menawan anggota organisasi sampai pada taraf tertentu. Dalam dunia kepemimpinan seringkali struktur itu jauh lebih mudah untuk mengubah perilaku. Gagasan tentang kewenangan atau spesifikasi "tugas-tugas" atau spesifikasi "tanggungjawab" seluruh persyaratan ini akan sangat berpengaruh terhadap perilaku kita, meskipun seringkali tidak kita sadari. Jika orang tetap bertahan maka ia harus mengubah perilakunya sesuai dengan struktur organisasinya, jika memberontak maka bisa dipastikan orang tersebut akan keluar dari struktur organisasinya.

\section{Perspektif Struktur Organisasi}

Negandhi (1975) menyatakan untuk membuat struktur organisasi yang tepat, dimulai dari melihat karakteristik fenomena birokrasi, dilakukan riset untuk mempelajari organisasi yang kompleks yang dapat menjelaskan sebab-sebab adanya struktur khusus dan mencari konsekwensi dari struktur-struktur khusus tersebut pada polapola perilaku dan efektivitas dari sebuah organisasi. Sedangkan penekanan yang harus dilakukan sekarang adalah untuk menetapkan alasan empirismengapa terjadi perbedaan derajat variasi pada struktur hirarki organisasi dan untuk menguji pengaruh pola struktur yang berbeda pada perilaku dan efektivitas organisasi. Chandler (1962) menyatakan bahwa struktur akan mengikuti strategi, hal ini sama dengan yang dinyatakan oleh Christensen et.al (1982). Menurut Chanler (1962), setelah merumuskan strategi perusahaan, managemen harus membuat desain struktur organisasi sebagai suatu prioritas utama hal ini karena perumusan strategi baru akan terjadi resistensi dan berbagai masalah administrasi baru akan muncul yang tentu saja berdampak pada kinerja organisasi, untuk mengatasi hal tersebut supaya tidak berlarut-larut maka diperlukan suatu struktur organisasi yang fit dengan strategi..

Chandler (1962) menggambarkan hubungan antara perumusan strategi, administrasi, kinerja organisasi, dan struktur organisasi sebagaiberikut: 


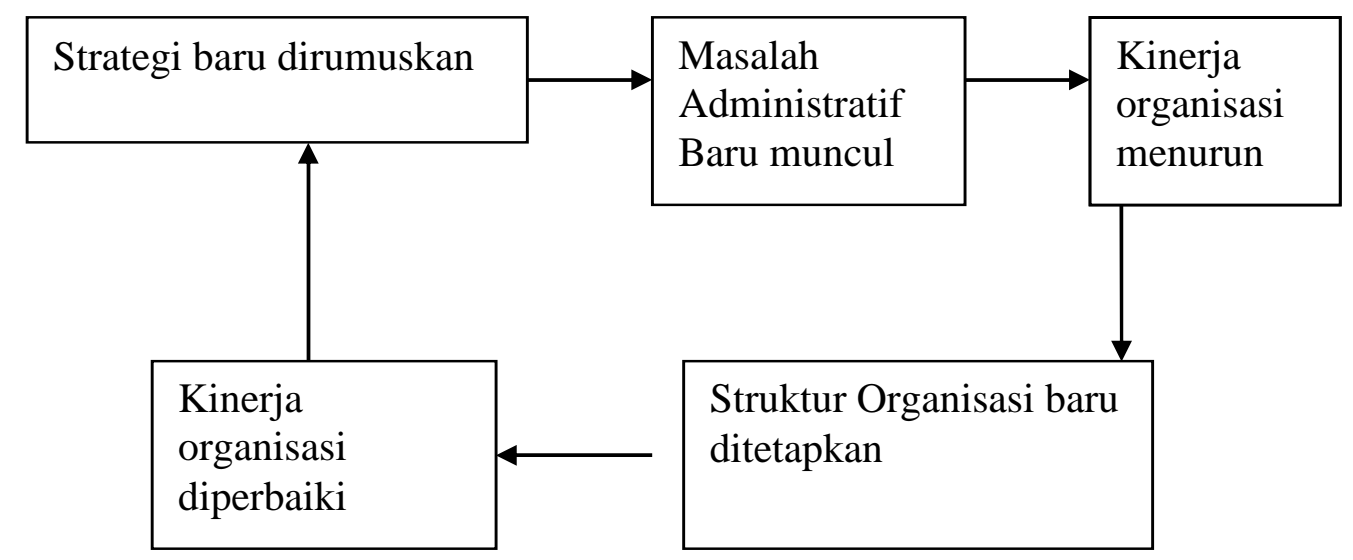

Implementasi strategi perusahaan dapat melalui disain organisasi. Desain organisasi mempunyai arti menyeleksi kombinasi struktur organisasi dan sistem pengawasan yang mengarahkan perusahaan untuk menerapkan strategi secara efektif yang akan menciptakan keunggulan bersaing. Peranan utama struktur organisasi dan pengawasan terdiri dari dua, yaitu: untuk mengkoordinasi kegiatan karyawan dan untuk memotivasi karyawan dan melengkapi mereka dengan insentif-insentif. Struktur organisasi dan kontrol membentuk orang-orang berperilaku dan menentukan bagaimana mereka bertindak dalam suatu organisasi.

\section{Dimensi Struktur Organisasi}

Pada tataran empiris, salah satu contohnya adalah Pugh at.al (1968) yang mengukur dimensi struktur organisasi. Ada lima dimensi utama dari struktur organisasi yang didefinisikan dan dioperasikan oleh penelitian empiris Pugh et.al (1968), yaitu spesialisasi, standarisasi, formalisasi, sentralisasi, dan konfigurasi. Hasilnya menyatakan bahwa ada beberapa perbedaan pandangan atas dimensi struktur, lima dimensi utama yang original dari struktur yang digunakan dalam penelitian Pugh et. al (1968) ini dianggap merupakan suatu sudut pandang yang lekat dengan unsur birokrasi, padahal di sisi lain dinyatakan oleh Blau bahwa jika konsep struktur adalah dari tipe birokrasi, maka hal tersebut tidak terlalu berguna. Selanjutnya hasil penelitian tersebut menyatakan bahwa ada empat dimensi struktur yang menjadi dasar taksonomi struktur organisasi, yaitu aktivitas struktur, konsentrasi autoritas, garis kontrol aliran kerja, ukuran relatif komponen pendukung.

Penelitian Pugh (1968) ini dilakukan dalam rangka menginvestigasi dan mengukur perbedaan struktur secara sistematis pada 46 organisasi di daerah Birmingham. Dimensi spesialisasi ini menitikberatkan pada pembagian tenaga kerja dalam organisasi, pendistribusian pekerjaan kantor dengan sejumlah posisi dan juga oleh spesialisasi peran. Dimensi standarisasi prosedur adalah aspek dasar struktur organisasional dan dalam istilah Weber akan membedakan organisasi birokratik dan tradisional dari organisasi karismatik, organisasi menstandarisasi prosedur seleksi. Dimensi Formalisasi menunjukkan sejauhmana aturan prosedur, instruksi, dan komunikasi tertulis. Dimensi Sentralisasi dilakukan dengan lokus autoritas untuk membuat keputusan mempengaruhi organisasi. Dimensi konfigurasi merupakan suatu bentuk struktur peran, yang berupa bagan organisasi komprehensif dan detil organisasi yang meliputi setiap literal dalam organisasi.

\section{Perkembangan Struktur Organisasi}


Pada awal tahun 1970 an struktur oragnisasi tradisional mulai ditinggalkan karena dianggap terlalu lamban dalam merespon peluang dan tantangan global. Selanjutnya perubahan struktur organisasi mengarah pada struktur organisasi yang dianggap modern yang lebih cepat dan fleksibel dalam merespon berbagai perubahan. Struktur organisasi modern tersebut adalah berbentuk network (jejaring) dan selular menurut Allred, et.al (1996). Struktur jejaring merupakan struktur organisasi yang berhubungan dengan perusahaan secara bebas untuk suatu penyediaan tenaga kerja yang berkeahlian khusus baik untuk suatu projek atau produk tertentu. Struktur ini memberikan keuntungan bagi perusahaan kecil karena perusahaan dapat menangani pekerjaan-pekerjaan yang tidak mungkin dikerjakan dengan sumber daya yang dimiliki, sedangkan bagi perusahaan besar akan dapat semakin cepat tanggap dan hemat biaya tentang apa yang harus dikerjakan. Akhirnya struktur network dapat memberikan pengaruh yang maksimal bagi penciptaan kompetensi inti perusahaan dengan melakukan hubungan dan kemitraan eksternal dan internal untuk membangun aktivitas lainnya dalam rantai nilai. Perubahan dalam struktur organisasi akan diikuti dengan kompetensi inti yang diperlukan oleh oragnisasi. Dalam hal ini, struktur jejaring mensyaratkan kompetensi inti tidak lagi sekadar kompetensi inti teknis tetapi meluas pada komersial dan kolaboratif. Sementara pada struktur organisasi selular maka kompetensi inti akan meluas pada tataran self-governance.

Perbedaan Struktur Organisasi Tradisional dan struktur organisasi Modern yang berkaitan dengan kompetensi inti serta implikasi pada pengembangan karyawan menurut Allred at.al (1996) tampak pada bagan berikut ini:

Struktur Organisasional Tradisional

\begin{tabular}{|l|l|l|l|}
\hline StrukturOrganisasi & Kompetensi Inti & $\begin{array}{l}\text { Responsibilitas untuk } \\
\text { Perencanaan Karier }\end{array}$ & Jalur Karier \\
\hline Fungsi Fungsional & $\begin{array}{l}\text { Perusahan Tunggal, } \\
\text { Within }\end{array}$ & Tekhnis & $\begin{array}{l}\text { Departemen } \\
\text { fungsional }\end{array}$ \\
\hline Divisional & $\begin{array}{l}\text { Perusahaan Tunggal, } \\
\text { lintas divisi }\end{array}$ & Tekhnis, komersial & Divisi, perusahaar \\
\hline Matriks & $\begin{array}{l}\text { Perusahaan tunggal, } \\
\text { lintas projek }\end{array}$ & Tekhnis, komersial & $\begin{array}{l}\text { Departemen, } \\
\text { projek, perusahaa }\end{array}$ \\
\hline
\end{tabular}

Sumber: Allred, Snow, dan Miles (1996)

Struktur Organisasional Modern

\begin{tabular}{|l|l|l|l|}
\hline $\begin{array}{l}\text { Struktur } \\
\text { Organisasi }\end{array}$ & Kompetensi Inti & $\begin{array}{l}\text { Responsibilitas untuk } \\
\text { Perencanaan Karier }\end{array}$ & Jalur Karier \\
\hline $\begin{array}{l}\text { Jejaring } \\
\text { (Network) }\end{array}$ & $\begin{array}{l}\text { Within dan Accros } \\
\text { Firms }\end{array}$ & $\begin{array}{l}\text { Tekhnis, komersial dan } \\
\text { Kolaboratif }\end{array}$ & $\begin{array}{l}\text { Perusahaan dan } \\
\text { Individual }\end{array}$ \\
\hline Seluler & $\begin{array}{l}\text { Profesional } \\
\text { Independen }\end{array}$ & $\begin{array}{l}\text { Tekhnis, komersial, } \\
\text { kolaboratif, dan self- } \\
\text { governance }\end{array}$ & Individual \\
\hline
\end{tabular}

Sumber: Allred, Snow, dan Miles (1996)

Dalam skema organisasi modern ini, jika struktur organisasi adalah struktur jejaring, maka memungkinkan karyawan berkarier di luar perusahaannya sesuai dengan pengetahuan dan keterampilan yang dimiliki. Sebaliknya perusahaan juga dapat memperoleh keterampilan dan pengetahuan yang diperlukan tanpa harus memiliki sendiri karyawan tersebut secara tetap. Dalam struktur ini tukar menukar 
karyawan antar perusahaan menjadi sesuatu hal yang biasa. Dengan struktur yang demikian maka karyawan harus mampu mengelola dirinya sendiri untuk meraih karier lintas perusahaan, sehingga karier tidak bergantung sepenuhnya pada tanggung jawab perusahaan akan tetapi menjadi tanggungjawab kedua belah pihak. Oleh karena itu karyawan dituntut memiliki kemampuan berkolaboras dan komersial di samping kemampuan tteknis.

Jika struktur organisasi yang dibentuk meru.pakan struktur organisasi selular yang merupakan struktur organisasi yang dibentuk oleh kelompok-kelompok yang mandiri, atau disebut juga unit-unit bisnis yang berotonomi yang dapat menunjukkan keberadaannya secara mandiri sebagai suatu organisasi seperti sebuah sel. Unit bisnis tersebut dapat bergabunng dan berinteraksi membentuk sebuah organisasi yang lebih besar. Perusahaan berfungsi sebagai penyedia atau pemberi untuk mengembangkan pengetahuan anggotanya. Setiap anggota mempunyai tanggungjawab terhadap karier mereka sendiri. Mereka bebas berkreasi sesuai dengan kesempatan dan keterampilan yang mereka kembangkan sendiri. Dalam model ini satu kemampuan yang dipersyaratkan bagi karyawan yakni kemampuan mengendalikan diri (self governance).

\section{Perkembangan Struktur Organisasi}

Dalam Taylor (1911) dalam Soetjipto (2004) yang memuncul ide awal mengenai Scientific Management dalam hal bertujuan untuk mengoptimalkan produktivitas pekerja maka yang harus dilakukan agar seseorang pekerja akan menjadi amat produktif apabila mengerjakan tugas-tugas tertentu dan sama secara berulang-ulang. Produktivitasnya menjadi optimal, karena ia menjadi mahir dalam mengerjakan tugas-tugas tersebut. Fayol (1949) dalam Soejito (2004) berargumentasi bahwa spesialisasi hanya dapat tercipta melalui pembagian kerja (diferensiasi horisontal) yang jelas. Diferensiasi sebagai pembagian kerja dapat dilihat secara horisontal dan secara vertikal.

Ostroff (1999) menganalogikan struktur organisasi horisontal mengingat rentang kendali setiap posisi yang lebih lebar dibandingkan dengan struktur organisasi mekanistik, sejalan dengan terdesentrasinya kewenangan sehingga struktur tampak mendatar (flat). Diferensiasi horisontal mengindikasikan pembagian kerja yang jelas antara posisi-posisi yang sejajar, namundemikian harus perlu suatu integrasi yang baik dan solid untuk mempercepat gerak langkah organisasi. Mengapa? Karena struktur organisasi horisontal ini mempunyai beberapa tugas yang menjadi tanggungjawab bersama, kewenangan terdistribusi pada posisi di level bawah (terdesentralisasi) Hal ini membawa konsekwensi mekanisme integrasi yang lebih rumit karena melalui komite atau kelompok kerja. Pembentukan komite atau kelompok pengintegrasi ini sebagai upaya mempercepat langkah organisasi.

Diferensiasi vertikal menggambarkan posisi-posisi yang berkedudukan tidak sejajar. Dalam diferensiasi vertikal ini lebih tepat disebut pembagian wewenang. Banyak pakar yang organisasi yang mengidentifikasikan struktur organisasi mekanistik sebagai struktur organisasi vertikal mengingat rentang kendali yang sempit sebagai akibat tidak ada desentralisasi kewenangan sehingga struktur terlihat meninggi. Dalam struktur organisasi mekanistik, pekerjaan terdiferensi dengan baik, kewenangan terpusat pada posisi di tingkat atas (tidak terdesentralisasi), hal ini menjadikan mekanisme integrasinya secara hirarkis. 


\section{Struktur kepemimpinan dan Organisasi}

Dengan bertumbuhnya organisasi maka bertambah pulalah jumlah karyawan, keragaman aktivitas yang harus dikontrol dan diintegrasikan. Untuk itu adalah jelas bahwa kita membutuhkan susunan-keteraturan serta integrasi yang lebih daripada sewaktu organisasi kita masih kecil.

Ada dua macam pendekatan ketika akan mengubah struktur organisasi, yaitu:

1. pendekatan penambahan hirarki dan formalisme

2. pendekatan pelonggaran organisasi dalam suatu bentuk jaringan-kerja yang lebih luas dan lebih terbuka

Kedua pendekatan ini secara umum nampak pada bermacam-macam organisasi. Dalam berbagai kondisi, pendekatan yang ketat juga harus mempertimbangkan pendekatan longgar dalam hal mengatasi krisis dan masalah koordinasi untuk mempertahankan para karyawannya, demikian pula sebaliknya, suatu pendakatan yang longgar juga perlu mempertimbangkan penyeimbang yaitu bersikap ketat dalam menjaga kesatuan. Kedua pendekatan ini bersifat strukturalis, yaitu struktur akan mempengaruhi perilaku. Pendekatan yang ketat menginginkan perilaku yang spesifik; sedangkan pendekatan yang kedua, menginginkan agar para karyawan menggunakan pikiran mereka secara kooperatif dan lebih terbuka. Dalam praktiknya pada suatu organisasinya biasanya melaksanakan kedua pendekatan, yaitu melakukan pengetatan dalam tataran bawah dan menciptakan kelonggaran pada tataran atas, dengan struktur yang lebih berlandaskan kepada tugas.

Pendekatan penambahan hirarki dan formalisme merupakan pendektana yang bersifat semakin memperketat ini hanya mengungkapkan sedikit sekali tentang sifat alami manusia. Pendekatan ini lebih condong ke arah pelaksanaan Tipe-A, yaitu usaha yang lebih lanjut untuk memperketat kontrol serta mempersempit bentukbentuk pekerjaan dan pencarian yang terus menerus ke arah perancangan organisasi yang bisa membebaskan dari sifat manusia yang merugikan. Cara pendekatan hirarki dimaksudkan melalui ketertiban yang bersifat impersonal. Pendekatan ini mencerminkan cara berpikir analitis yang mula-mula meninjau tentang tugas dan barulah kemudian tentang persyaratan organisasi. Cara pendekatan ini mencoba untuk melakukan spesifikasi terhadap jalur-jalur komunikasi, mengencangkan kekendoran, penempatan tanggungjawab secara tepat, menghilangkan tugas yang kembar, serta memonitor langkah pendekatan itu sendiri dengan teliti. Logika yang digunakan adalah logika tentang kumpulan bagian-bagian. Kerja yang efektif dicirikan dengan memastikan bahwa A, B, C, dan D melaksanakan tugasnya sesuai dengan jadwal dan mengantarkannya ke tempat yang tepat.

Pendekatan struktur yang ketat mempunyai sifat yang lebih tegas dan lebih tertib. Dalam struktur yang ketat maka perintah-perintah dapat diberikan pada bawahan. Karyawan bisa sangat hormat kepada atasannya dalam arti hormat yang berlebihlebihan, adapun terjadi perlakuan yang wajar namundemikian sifatnya adalah impersonal.

Kelemahannya adalah:

1. struktur ini tidak luwes, sehingga sulit menerima gagasan-gagasan yang kreatif dan unik.

2. bawahan tidak berani mengambil keputusan-keputusan sehingga menunggu pendapat atasannya

3. adanya kemungkinan bawahan bersikap tidak jujur 
Pendekatan yang kedua, adalah pendekatan yang berpandangan bahwa struktur hanyalah merupakan penunjang motivasi.Dalam pendekatan ini melalui jaringankerja yang longgara memperlakukan struktur sebagai masalah nomer dua, yang diutamakan pada pendekatan ini adalah para karyawan. Pendekatan ini berawal dari pendapat yang mengatakan bahwa manusia secara alamiah telah dibekali dengan motivasi, dan mereka adalah makhluk yang produktif. Pendekatan ini berorientasi pada karyawan yang pada umumnya juga merupakan pendukung bentuk desentralisasi, bentuk organisasi-matriks bagi kreativitas, bagi skema-skema pengkayaan kerja (job-enrichment), dan lebih menekankan kepada tanggungjawab kelompok daripada tanggungjawab individual. Ang ditekankan dalam hal ini adalah pembinaan motivasi, krativitas, pengembangan personil, tantangan serta pembinaan sikap kepemilikan. Dalam hal ini diperlukan suatu struktur yang luwes, yang khusus, yang seringkali hanya bersifat sementara untuk menyediakan sebuah tempat yang layak bagi para personil yang memiliki dorongan untuk berkembang. Struktur yang luwes dalam jangka panjang akan membuahkan hasil yang lebih produktif.

Kelemahan:

1. sedikit sekali terjadi umpan balik atas hal-hal yang manager sudah laksanakan

2. bawahan tidak menaruh perhatian pada atasannya

3. seolah-olah mengatur pasar bergaya Asia, yang pada setiap individu menawar bagian kegiatan masing-masing

\section{SIMPULAN}

Pada awal tahun 1970 an struktur organisasi tradisional mulai ditinggalkan karena dianggap terlalu lamban dalam merespon peluang dan tantangan global. Selanjutnya perubahan struktur organisasi mengarah pada struktur organisasi yang dianggap modern yang lebih cepat dan fleksibel dalam merespon berbagai perubahan. Implementasi strategi perusahaan dapat melalui disain organisasi. Desain organisasi mempunyai arti menyeleksi kombinasi struktur organisasi dan sistem pengawasan yang mengarahkan perusahaan untuk menerapkan strategi secara efektif yang akan menciptakan keunggulan bersaing.

Peranan utama struktur organisasi dan pengawasan terdiri dari dua, yaitu: untuk mengkoordinasi kegiatan karyawan dan untuk memotivasi karyawan dan melengkapi mereka dengan insentif-insentif. Struktur organisasi dan kontrol membentuk orangorang berperilaku dan menentukan bagaimana mereka bertindak dalam suatu organisasi.

Stuktur organisasi ternyata sangat berpengaruh dalam mengubah perilaku dan nilai karakteristik anggota organisasi. Struktur organisasi adalah pengontrol perilaku. Perubahan terhadap struktur organisasi sudah pasti dimaksudkan sebagai upaya mengubah perilaku. 


\section{DAFTAR PUSTAKA}

Handoko, Hani. Dalam wawancara oleh Usahawan.1996. Rancang Ulang Struktur Organisasi. Usahawan. April, No.04 Thn XXV

Handoko, Hani. dan Tjiptono, Fandy. 1996. Kepemimpinan Transformasional dan Pemberdayaan. JEBI. September

House, R.J. \& Aditay, R.1977. The social scientific study of leadership: Quo vadis Journal of Management, 23: 409-473.

Leavitt, Harold J. 1978.Managerial Psychology. The University of Chicago

Meindl, J.R., Ehrlich, S.B., \& Dukerich, J.M.. 1985.The romance of leadership. Administrative Science Quarterly, 30: 78-102.

Miner. 1980.Theories of Organizational Behavior, chapter 10, 11, 12, 13. The Dryden Press.

Negandhi, Anant. R. 1975. Comparative Management and Organization Theory: A Marriage Needed.Academy of Management Journal, vol. 18 Number-2, June, 1975

Ostroff, F. 1999. The horizontal organization. New York: Oxford University Press.

Pfeffer, J. 1977 .The ambiguity of leadership. Academy of Management Review, 2: 104112.

Pfeffer, Jeffrey.1982. Organizations and Organization Theory. Pitman Publishing Inc.

Perrow, C..1970.Departemental power and perspective in industrial firms. In M. N. Zald (Ed.), Power in Organizations. 59-89. Nashville, T.N: Vanderbilt University Press.

Pugh, D.S. et al.1986. Dimensions of organizational structure. Administrative Science Quarterly. 13: 65-105

Provan, K. G.1980.Recognizing, Measuring, and Interpreting the potential/enacted power distinction in organizational research. Academy of Management Review, 5: 549-560.

Starbuck, W. 1981.A trip to view the elephants and rattlesnakes in the garden of Aston. In A Van de Ven \& W.F. Joyce (Eds.), Perspectives in Organization Design: 1967199, New York: Wiley.

Schoonhoven, C. B.1981.Problems with contingency theory: Testing assumptions hidden within the language of contingency 'theory'. Administrative Science Quarterly, 26: 349-378 
Soetjipto, Budi,. W.2004.Struktur Organisasi dan Lingkungan Usaha Masa Depan. Usahawan. LPPM UI

Stoner, J.A. \& Freeman, R. E.1992. Management ( $5^{\text {th }}$ ed.). Englewood Cliffs: Prentice Hall.

Yukl, Gary A.1989. Managerial leadership: a review of theory and research. Journal of management, 15: 251-289 